Luxus für alle 



\section{Luxus für alle}

\section{Meilensteine im europäischen Terrassenwohnbau}

Gerhard Steixner

Maria Welzig

(Hg.)

Birkhäuser

Basel 